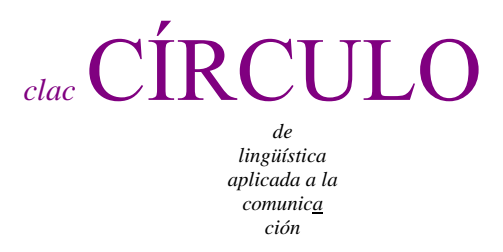

$59 / 2014$

\title{
LA PARODIA INFORMATIVA COMO FRIVOLIZACIÓN DEL DISCURSO POLÍTICO
}

Elena Méndez García de Paredes

\author{
Universidad de Sevilla
}

emendez en us es

\section{Resumen}

El humor es una realidad compleja pero, pese a su ambivalencia y ambigüedad, resulta una estrategia válida para determinados objetivos comunicativos. Es lo que ocurre con la parodia informativa que va ligada a la actualidad mediática. Esta representa lo serio sea por contigüidad sea por evocación mientras que la parodia informativa convierte los acontecimientos, la noticia o a sus protagonistas, en blancos de humor. Este artículo analiza el contexto de los medios de comunicación y los mecanismos discursivos y lingüísticos de este humor paródico como estrategia para seducir a la audiencia en nuevos formatos de televisión. Los mecanismos discursivos atañen al fenómeno de la enunciación y al acto de comunicación. Los lingüísticos, a los mecanismos verbales que se ponen al servicio del acto de enunciación humorística.

Palabras clave: enunciación humorística, procedimientos lingüísticos y procedimientos enunciativos, parodia informativa, intertextualidad cómica.

Elena Méndez García de Paredes. 2014.

La parodia informativa como frivolización del discurso político. Círculo de Lingüística Aplicada a la Comunicación 59, 61-91. http://www.ucm.es/info/circulo/no59/mendez.pdf http://revistas.ucm.es/index.php/CLAC http://dx.doi.org/10.5209/rev_CLAC.2014.v59.46709

(C) 2014 Elena Méndez García de Paredes

CÍRCULO de Lingüística Aplicada a la Comunicación (clac)

Universidad Complutense de Madrid. ISSN 1576-4737. http://www.ucm.es/info/circulo 


\begin{abstract}
Informative parody as a trivialization of political discourse. Humour is a complex reality but, despite its ambivalence and ambiguity, it can be a valid strategy for certain communicative goals. This is what happens with informative parody. It linked to current news. This represents the serious by presence or by absence or evocation, whereas informative parody becomes events, figures, speeches, news in target of the humor. This paper analyzes the context of the Spanish media, and the discursive and linguistic mechanisms or procedures of parody humor as strategies to capture the TV audience. Discursive procedures concern the statement and the act of communication. Linguistic procedures are verbal mechanisms which are at the service of the humorous utterance.
\end{abstract}

Key words: Humorous enunciation, linguistic procedures and statement processes, informative parody, humorous intertextuality

Índice

1. Introducción, 62

2. Formatos de humor basados en la actualidad informativa, 64

3. El humor como estrategia de captación de audiencia, 72

4. La parodia como procedimiento discursivo en el humor informativo, 77

5. El molde comunicativo elegido, 82

6. Los blancos de humor y el efecto crítico, 86

7. Conclusión, 88

8. Bibliografía, 88

\title{
1. Introducción
}

En España, la parodia informativa se generalizó y se hizo popular con la aparición las nuevas radios en los años ochenta, coincidiendo con una paulatina estabilización de su incipiente democracia. El debate de la nación o sobre el estado de la nación, dentro del programa 
radiofónico Protagonistas ${ }^{1}$, dirigido por Luis del Olmo fue en esa época uno de los espacios más populares de sátira política protagonizada por humoristas de reconocida maestría en el panorama español como Luis Sánchez Polack (Tip), José Luis Coll, Miguel Gila, Chummy Chúmez, Mariano Ozores, y por algún columnista político como Alfonso Ussía. Una sátira política que, si bien no era novedad en España, pues hundía sus raíces en una tradición de revistas satíricas como, por ejemplo, La Codorniz (1941-1978), Hermano Lobo (1972-1976) o Por favor (1974-1978), sí lo era con respecto al nuevo formato mediático, insertado en un programa radiofónico de actualidad en que se trataban hechos diversos. Se combinaba, pues, la información con el entretenimiento, lo que determinó un carácter híbrido que ha repercutido en los formatos que llegado a tener el humor informativo de televisión basado en la actualidad mediática.

No es hasta mediados de los años noventa, coincidiendo con la aparición de las televisiones privadas, cuando la parodia informativa empieza a hacerse tímidamente un hueco en las parrillas de la programación televisiva española como una estrategia de captación de audiencia ${ }^{2}$. Se trata de programas conformados con un estilo aparentemente informativo, cuyos temas parodian la realidad informativa de la que se habla en los informativos serios, si bien es el discurso político y sus enunciadores, así como el concepto de "relevancia informativa", como garante de la actualidad noticiable, lo que constituye principalmente el blanco del humor. Los responsables de la mayoría

\footnotetext{
${ }^{1}$ Un espacio que desde sus orígenes estuvo vinculado al de su director y que fue emitiéndose en las diferentes emisoras radiofónicas en las que fue trabajando el periodista Luis del Olmo (RNE, Cadena Cope, Radio Popular, Onda Cero o Punto Radio).

${ }^{2}$ En esa década se produce en España un cambio en el panorama televisivo y se pasa de la llamada paleotelevisión a la neotelevisión (Eco 1983). La primera, monopolio de los Estados, es una forma de comunicación unidireccional, cuyo objetivo (informar, formar y entretener) descuida el carácter estratégico que ha de tener una programación. El resultado es un destinatario pasivo que o consume o apaga la televisión. La segunda, es comercial y se guía por una política empresarial dependiente de la publicidad, en tanto que las cadenas compiten unas con otras por hacerse con una importante cartera de clientes que quieran insertar sus anuncios dentro de determinados espacios. La programación adquiere un carácter estratégico porque el espectador se vuelve activo y las cadenas han de seducirlo y fidelizarlo. Como la audiencia es determinante, desde un punto de vista económico, ha de ser cuidadosamente estudiada y se mide cuantitativa y cualitativamente para determinar el target o segmento de población a que se destina el producto televisivo (Cortés 1999).
} 
de esos programas humorísticos, originados a comienzos de la neotelevisión, comparten unas características semejantes: la edad (entre los 40 y 50 años) o la experiencia profesional (el mundo de la radio $^{3}$ que, como se ha dicho ya, fue el germen de los programas humorísticos basados en el formato paródico) y la ideología subyacente, por lo que es coherente pensar que lo que resultaron ser nuevos formatos para televisión han tenido una impronta generacional, que ha ido consolidándose con el paso de los años, hasta llegar a ser un nuevo género televisivo que proporciona una imagen de marca a las cadenas que los emiten (Cortés 1999,Valhongo Crego 2011). Por su parte, el público a quien va destinada la parodia informativa queda configurado por estos programas como un espectador activo e inteligente que se siente cómplice de este humor y disfruta ante la visión descreída de la actualidad periodística que se le ofrece desde una distancia humorística, más propia de un espectáculo televisivo que de un programa informativo (Méndez $G^{\text {a }}$ de Paredes 2004 y Valhongo Crego 2011).

\section{Formatos de humor basados en la actualidad informativa}

La situación de comunicación es el marco de referencia al que se remiten los hablantes para dar valor y sentido a los actos de habla, de ahí que sus normas y convenciones se regulen socialmente de un modo implícito. Por ello, además de que no es posible otorgar sentido a un mensaje al margen de su contexto comunicativo, se hace necesario extraer de la situación de comunicación los datos relevantes que se requieren para dar sentido e interpretar adecuadamente los actos de habla emitidos ${ }^{4}$. Pues bien, al basarse estos programas en la actualidad informativa, esta actualidad o, más concretamente, la

\footnotetext{
${ }^{3}$ A modo de ejemplo, el director de El Informal (Telecinco: 1998-2002) era Javier Capitán que procedía de RNE, donde realizaba imitaciones paródicas de los principales políticos. Tony Martínez, director de Las noticias del guiñol (Canal +: 1995-2005 y Canal +/ Cuatro: 2005-2008), también trabajó en RNE, al igual que Eduardo Arroyo (Caiga quien caiga en Telecinco: 1996-2002 y 2005-2008), escritor durante un corto tiempo de guiones para la radio.

4 Como señala Charaudeau (1989, 1991, 1993, 1994, 2003, 2006), estos datos tienen una doble naturaleza: unos son externos, de carácter situacional, y definen la identidad social de la instancia de producción o de emisión (roles sociales, propósito comunicativo, dispositivos empleados, temas sobre los que se habla). Otros son internos, de carácter discursivo y lingüístico, configuran las identidades enunciativas, definidas por los modos de hablar y de inscribir en el discurso participantes y temas.
} 
construcción de la actualidad por parte del discurso mediático se convierte en blanco del humor y ello puede hacerse por simple juego lúdico, propio de los programas de entretenimiento o con una finalidad más profunda y seria que trata de enjuiciar la realidad construida por el discurso mediático, ofreciendo una mirada diferente de los fenómenos sociales y políticos que se aparta y se distancia de lo transmitido por los diferentes medios. De ahí que la parodia informativa de estos formatos pueda plantearse también seriamente como un tipo de humor "serio" que pueda contraponerse de un modo alternativo al discurso informativo oficial (Massi 2008). Por ello, como en cualquier otro tipo de discursos, el destinatario de estos programas de entretenimiento debe dar sentido a lo que percibe, confrontándolo con su conocimiento del mundo, sus creencias, las del grupo social en que se incluye o del que disocia, determinando en cada momento en qué lugar del continuum (+/-) humorístico ha de situar para su interpretación lo que el medio le propone. Se convierte así en un destinatario activo que consume la información humorística de los medios. Para ello se sitúa en un punto intermedio entre la posición que le asigna el medio (por el modo en que se lo concibe en y se dirige a él), y la posición que se le atribuye dentro de los procesos sociales de referencia en los que participa. Esto determina su integración en un target de audiencia, que es tenido en cuenta en la configuración de estos programas (Cassetti/di Chio 19).

Con respecto al humor informativo en los medios de comunicación, los datos externos (vid. Nota 4) permiten acotar un tipo de humor institucionalizado de tipo paródico: la parodia informativa (representada por espacios televisivos como El Informal, Las noticias del guiñol, Caiga quien caiga, Noche Hache, Sé lo que hicisteis, Homo zapping o El Intermedio, o radiofónicos como Gomaespuma o No somos nadie en M-80 Radio Y en la Cadena Ser Todo por la radio, un espacio humorístico emitido antes en Hoy por hoy y, en la actualidad, en elprograma La ventana $)^{5}$, y diferenciarlo de otro tipo de

\footnotetext{
${ }^{5}$ El Informal se emitió desde julio de 1998 a abril de 2002 en la cadena Telecinco (premios: Antena de oro en 1998, TP de oro al mejor programa de actualidad y reportajes en 1999, 2000 y 2001, Premio Ondas al mejor programa de entretenimiento 2001 y GECA al programa de humor con más seguimiento en 1999). Las noticias del guiñol se emitió desde 1995 en Canal + y desde 2005 a 2008 en Canal + y Cuatro (Premio Ondas de guion y premios ATV). Caiga quien caiga desde 1996 a 2002 y de 2005 a 2008 en Telecinco (Premio Ondas al programa más innovador en 1997, TP de Oro al mejor programa de actualidad en 1997, MIDIA 1998 al mejor programa de entretenimiento, Premio del Club internacional de la Prensa 1998, etc. Después de su desaparición en 2003, fue nominado en cinco categorías en los
} 
humor que puede aparecer al hilo del discurso serio. No tanto como parodia de un género (la noticia periodística), sino más bien como alteración del estilo asignado a un modo de decir, que se coloquializa y permite un tratamiento humorístico o más frívolo de la noticia, cuando lo esperable es un estilo formal, en consonancia con la situación de comunicación en que se inserta. Se trata, por ejemplo, del tratamiento discursivo que se da a algunos contenidos informativos susceptibles de admitir ese enfoque lúdico: deportes, hechos diversos de la actualidad social, televisiva, cinematográfica (lo que algunos han denominado "noticias blandas" (Valhongo Crego 2011) que, si bien participan de un tono lúdico, no son propiamente fenómenos paródicos.

Por su parte, los diferentes formatos y géneros facilitan, en principio, la recepción e interpretación de los productos mediáticos de tipo humorístico, pero no siempre ello se consigue felizmente: bien porque no están bien definidos para el público que los consume, bien porque, en la lucha por la audiencia, se están renovando continuamente y tienden no solo a la copia y adaptación de formatos e ideas procedentes de otros países ${ }^{6}$, sino a la hibridación de formatos diversos. Esto hace muy dinámica la programación y determinan la creación de nuevos géneros televisivos (Valhongo Crego 2011), que no siempre son bien interpretados por los espectadores.

Recientemente hemos podido asistir a las reacciones contrapuestas que suscitó un nuevo experimento de parodia informativa en que la hibridación lúdica periodismo+ficción no fue bien interpretada por la audiencia. Se trata de Operación Palace, dirigido y presentado por Jordi Évole que emitió La Sexta TV el domingo 23 de febrero de 2014. Operación Palace fue una muestra de lo se conoce como pastiche cómico (se subvierten los valores periodísticos y se incorporan a la parodia informativa falsos datos o testimonios deformados que tienen un exceso de conformidad con los rasgos estilísticos del modelo informativo), una humorada muy bien construida sobre los acontecimientos de

premios ATV). Homo Zapping se emitió desde 2003 a 2007 en Antena 3. (Premios: Premio Ondas al mejor programa de entretenimiento 2004, el Premio ATV en 2005, TP de Oro en 2005. El Intermedio se emite en la Sexta Televisión desde 2006. Su presentador, El Gran Wyoming, ha recibido varios premios de la ATV al mejor presentador (2008, 2011 y 2012), ATV al mejor programa de entretenimiento 2011 y 2012 y al mejor guion 2012 (Sangro/Salgado 2008 y La Sexta Televisión 2013).

${ }^{6}$ Por ejemplo, Caiga quien caiga se exportó de la televisión argentina, Las noticias del guiñol se inspiran en Les guignols de l'info y estos en los Spitting Image de la televisión británica. 
El 23-F. Como parodia de Salvados, no podía despegarse demasiado de la estructura de este programa, salvo en el contenido de los testimonios de políticos, periodistas, militares y agentes sociales de reconocido prestigio, que aportaban una información absolutamente desconocida pero, a la vez, insólita y paradójica ${ }^{7}$, que fue interpretada por la audiencia en términos de credibilidad. Las expectativas de la audiencia, pese a las advertencias de Jordi Évole ${ }^{8}$, estaban puestas en un programa informativo especial, de características semejantes a Salvados, que explicara y recordara el intento de golpe de Estado del 23 de febrero de 1981. El formato en ningún momento llegaba a desmentir las expectativas depositadas por la audiencia: parecía seguir las rutinas de un periodismo de investigación que estaba aportando nuevos datos y proporcionando una mirada diferente a lo consabido. Para los espectadores todo parecía estar funcionando conforme a lo esperado, y en consonancia con la imagen que director y conductor de Salvados, Jordi Évole, ha proyectado de sí mismo a lo largo de su carrera ${ }^{9}$. El engaño fue mayúsculo porque la mayoría de la audiencia interpretó “en serio", lo que había sido ideado como un híbrido de ficción de tipo paródico ${ }^{10}$. Lo que, a juicio de Évole, no fue

\footnotetext{
${ }^{7}$ El montaje humorístico reconstruía una nueva visión de los hechos acontecidos: presentaba el intento de golpe de estado de Tejero del 23 de febrero de 1981 como una pantomima. Según el supuesto reportaje, se habría tratado de una representación teatral que habría requerido la confabulación de todas las fuerzas políticas, de la Casa Real y de la cúpula militar, para cohesionar a la población española en torno a su clase política y a la monarquía. De este modo, el miedo efectivo a perder la reciente democracia permitiría hacer frente a posibles intentonas reales de golpes de estado que estuvieran fraguándose.

${ }^{8}$ Évole hizo publicidad de este programa, advirtiendo de que era un experimento que debía ser visto en su integridad antes de emitir un juicio, y señalando que se complementaba con un debate posterior sobre el programa. http://www.lasexta.com/especiales/operacion-palace-23f/recuerdo-haber-visto-algo-este-nivelsorpresa_2014022000194.html (última consulta 3/03/2014).

${ }^{9}$ Una imagen de periodista de calidad, transparente, desenfadado e incisivo, que no ceja en su empeño de construir verazmente la información que "a medias" o interesadamente construyen los medios, yendo incluso más allá de lo que es esperable en un periodismo de investigación.

10 Consecuentemente, se sucedieron durante toda la noche airadas reacciones de enfado de los espectadores. Un total de 4.855 mensajes de telespectadores por minuto, según datos de Global in Media, se sucedieron al término del programa, cuando Évole desveló que se trataba de una licencia periodística que nada tenía que ver con la verdad de los acontecimientos. Para estos datos, puede consultarse:
}

http://laguiatv.abc.es/loultimo/20140224/abci-reacciones-operacion-palace-201402241254.html. 
más que un intento de arriesgar y experimentar con las fronteras de lo periodístico y la ficción, construyendo un nuevo género híbrido, no fue entendido por la audiencia por varias razones: a) desubicación con respecto a la posición que el formato del programa pretendía asignarle, b) porque los indicios de humor que se propusieron para su reconocimiento no fueron suficientemente evidentes y c) porque el humor tiene también sus propios tabúes y hay temas sensibles en los que el engaño humorístico debe estar muy bien calculado para que confluyan bien los tres planos requeridos en el funcionamiento del humor: el del enunciador, el del enunciatario y el del objetivo o blanco del humor (Bustos 2006, Charaudeau 2006) ${ }^{11}$.

Simplificando mucho, los géneros mediáticos que componen la programación de las diferentes cadenas suelen agruparse en tres grandes categorías: una referencial, integrada por los diferentes géneros y subgéneros que tienen como objetivo temático los acontecimientos y personas del mundo real, cuyo contrato de comunicación se basa en la información (o en los juicios y evaluaciones que suscita esta) y, por tanto, en la credibilidad que nos proporciona su autenticidad; otra ficcional que elabora mundos virtuales (cuyas referencias no pueden ser más que internas al propio relato) y establece un contrato de comunicación basado en la simulación, el fingimiento o la incredulidad, en el que opera una jerarquía de máximos semánticos, según la cual lo inverosímil prima sobre lo verosímil y lo verosímil sobre la autenticidad referencial de lo real; y una última categoría híbrida por intersección de las dos precedentes que tiende a mezclar realidad y ficción, sea en su estructura textual, sea en sus contenidos, sea en ambos a la vez. El contrato de comunicación en estos géneros es ambivalente y obliga a una tensión en cuanto al posicionamiento que debe ser adoptado con respecto a la (in)credulidad y nos lleva a tener una actitud escéptica que necesita ser resuelta en una u otra dirección (Sangro/Salgado 2008) ${ }^{12}$.

\footnotetext{
${ }^{11}$ No calcular bien el humor informativo tiene graves riesgos tal y como se puso de manifiesto en los comentarios que se sucedieron en todos los medios a lo largo de la semana: explotar los límites del periodismo lleva consigo el riesgo de perder la credibilidad social requerida en el contrato de comunicación periodística, dado que confunde y desorienta a la audiencia, al hibridar realidad-ficción, sin previo aviso, dentro de un formato periodístico.

${ }^{12}$ Anteriormente, U. Eco (1983) ya había propuesto distinguir una tipología de espacios de programación televisiva parecida a la descrita: informativos (los contenidos enunciados se verifican independientemente de ella y los criterios que se presuponen son veracidad, relevancia informativa, proporción, así como
} 
Dentro de esta última categoría es donde hay que situar los géneros de parodia informativa para los que se han propuesto los anglicismos infotainment o infoshow (Sangro/Salgado 2008) ${ }^{13}$ alusivos a su hibridez, ya que en ellos se mezcla el propósito de captación, inherente a los géneros de entretenimiento, con el propósito de información (cf. los enunciados que suelen aparecer en ciertos programas: “¡Ya conocen las noticias! Ahora les contaremos la verdad”, que es el comienzo de cada programa de El intermedio; o "Bienvenidos a Caiga quien caiga, el único programa informativo que desnuda por completo la actualidad para ofrecérsela a ustedes", que era uno de los mensajes más recurrentes de $C Q C)$. El carácter híbrido del formato permite reconocer en estos programas géneros informativos identificables, como pueden ser la noticia, el reportaje o la entrevista, así como procedimientos periodísticos: testimonios directos con reporteros, etc. de los que se vale el quehacer informativo mediático (Hidalgo Downing 2009). Esto hace posible que sean divulgadores de noticias, pues es la información periodística la que surte de temas a estos programas, que se realizan, además, aprovechando los fondos documentales de los informativos serios ${ }^{14}$. Por otro lado, el tratamiento humorístico proporciona el marco interaccional que se proyecta en diferentes niveles del discurso y en la alternancia del rol de periodista y humorista. El

separación de información y comentario); y de ficción (espectáculos: que implican un pacto de suspensión de la credulidad que juega a tomar por serio lo que no es más que un efecto de construcción fantástica). A su vez los relaciona con la posición enunciativa hablar mirando a la cámara (no está en cuestión la veracidad del enunciado, i. e., la concordancia de lo dicho y los hechos, sino la veracidad de la enunciación, que concierne a la cuota de realidad de lo que sucede en la pantalla), frente a hablar sin mirar a cámara (en donde la televisión desaparece en tanto que sujeto del acto de enunciación, aunque se presupone presente: los debatientes hablan sin mirar a cámara, los protagonistas reales de un hecho no miran a cámara cuando la cámara los filma, como si todo formase parte de la vida real extratelevisiva (se atenúan las diferencias entre información y espectáculo). A ello hay que sumar, según Eco, la entrada de un híbrido televisivo que pone en cuestión la veracidad de los enunciados (en tanto que es ambigua), mientras que la veracidad del acto de enunciación es indiscutible (el presentador ante la cámara se representa a sí mismo y habla al público no como un personaje de ficción).

${ }^{13}$ Recientemente se ha propuesto el término infosátira (Valhongo Crego 2011) para la combinación de noticia periodística y formato paródico y humorístico, precisamente por el efecto crítico de sátira políticosocial, que es el sello distintivo de estos programas mediáticos.

${ }^{14}$ Según el estudio de Valhongo, la popularización de la infosátira se traduce en cifras de audiencia y constituye un 75\% más de cuota de pantalla que las del telediario de mayor audiencia TV1 (Valhongo 2011: 193). 
resultado puede ser un grado variable de proximidad-alejamiento de la realidad que puede variar en función del programa $\mathrm{y}$, aun dentro de este, según las secciones ${ }^{15}$.

La vis cómica de la parodia informativa, incide sobre los valores periodísticos y sobre la retórica del discurso mediático (Van Dijk 1990). Desmonta la actualidad informativa, cuestionando su pertinencia e incluso su veracidad ("Estas son la noticias que no interesan a nadie pero que contamos porque nos salen baratas", en Sé lo que hicisteis 27/10/2009 en la sección "Lo que está pasando"). Por esta razón, la distancia humorística con que se trata la información deja al descubierto el otro lado de la producción de la noticia y aporta una nueva perspectiva sobre los acontecimientos que acaparan la actualidad informativa ${ }^{16}$. Ello se consigue no solo mediante el nuevo formato de estos programas y los dispositivos empleados (los datos externos que provienen de la situación de comunicación) sino, también, lingüísticamente por la modificación del estilo que la historia de la tradición discursiva ha asignado al discurso de la información mediática (Hidalgo Downing/Iglesias Recuero 2006), cuya formalidad es, precisamente, lo que le confiere legitimidad y veracidad ${ }^{17}$. En estos

${ }^{15}$ Por ejemplo, en Las noticias del guiñol hay un tratamiento ficcional de la actualidad informativa, representada por muñecos de látex que se identifican claramente con políticos y personajes públicos. En El intermedio, la actualidad informativa es real pero el comentario de esta se hace en clave humorística. Sin embargo, en este mismo programa, la sección de vídeos manipulados, donde el empleo de efectos de grafismos y animación se superponen a imágenes de la realidad, provocando un choque de mundos aparentemente incompatibles, es un juego entre realidad y ficción que permite ver a personajes de la esfera pública, como el rey o el presidente del Gobierno mandándose por WhatsApp mensajes de complicidad con el entrenador del Real Madrid, J. Mourinho.

${ }^{16}$ En estos casos, la parodia informativa actúa como un supradiscurso o superdiscurso: contiene polifónicamente otros discursos, permitiéndose lo que los informativos serios no pueden hacer, desmontar la producción de la noticia, relativizando la veracidad de la información oficial (Méndez- $G^{a}$ de Paredes 2013).

${ }^{17}$ En sentido general, como señala Van Dijk, "el estilo es el conjunto total de los detalles estructurales variables y característicos del discurso que son una indicación del contexto social y personal del hablante, dada una invariante semántica, pragmática o situacional" (1990: 111). Ello quiere decir que hay distintos tipos de estilos que, además, suelen asociarse entre sí: uno contextual, asociado a un tipo de contexto particular (por ejemplo, el de la comunicación mediática), otro funcional en el que las características del lenguaje usado son dependientes del rol profesional que se desempeña (periodista), otro discursivo, relacionado con el género de discurso específico que se asume al hablar (el de la información periodística, de carácter impersonal, temático, formal y estandarizado). 
nuevos géneros, los modos discursivos adoptan un carácter conversacional (personalizado y subjetivo, propio de temas cotidianos) y un empleo del registro coloquial (no formal ni estandarizado), tal y como puede verse en la siguiente noticia dada en un espacio radiofónico que combina información y entretenimiento:

CA: "Berlusconi promete bailarinas a los obreros de L' Aquila"

CM: Berlusconi está metido en una espiral de de [de

CA:

[está enloquecido

CM:

[de desvergüenza y desatino§

JC:

§oye

que los obreros estarán contentos

CA: bueno/ pues el primer ministro italiano visitó de nuevo la ciudad que en abril resultó sacudida por el terremoto / y aprovechó para hacer bromas sobre los escándalos sexuales que le rodean§

CM: $\quad$ \$muy apropiado Berlusconi!!

CA: sí sí/ en un mensaje para los obreros Berlusconi dijo que si todo iba bien traería bailarinas porque si no les tomarían por homosexuales§

CM:

$\S$ eh esta es un poco la gracia de este señor

CA: "si todo va bien traeré bailarinas para que no os tomen por homosexuales"/ con menos palabras no se puede joder a más gente (No somos nadie 26/6/2009). ${ }^{18}$

Tras la lectura del titular por la periodista, Celia Montalbán (C. M.), se inicia una interacción conversacional de comentarios al titular por parte de otro periodista, Carlos Areces (C. A.), que se ve jalonada por secuencias de lectura de la información, a dos bandas, para completar la noticia. La coloquialización del estilo determina el tono (key) dado a la información, y la inserción de marcadores (bueno y pues) avisan del cambio que se opera en la interacción: marcan el paso de una secuencia de comentario a otra de continuación con el discurso informativo anterior y lectura de la noticia. Por otro lado, la secuencia en estilo directo de la última intervención es propia del discurso serio de la noticia y funciona como prueba de la autenticidad y veracidad, tanto de lo dicho como del propio acto de decir periodístico (Méndez $\mathrm{G}^{\mathrm{a}}$ de Paredes 1999). Además, sirve como contrapunto real a la intervención inicial, con la que C. A. emite el titular de la noticia. Este titular podría ser tomado por los oyentes como una exageración o como algo increíble que está fuera de una actuación política de ayuda a los damnificados por el terremoto y más propio de un posicionamiento lúdico dentro de la enunciación humorística, de manera que el estilo directo produce un efecto de objetivación y

\footnotetext{
${ }^{18} \mathrm{CM}=$ Celia Montalbán y CA = Carlos Areces. Vid. http://www.podcast-es.net/podcasts/m80-radio-no-somosnadie-72467.html (consultado el 29 de noviembre 2009).
} 
autentificación de un decir que ha de interpretarse, pese al tono lúdico de la interacción, como informativo.

La información modifica su naturaleza por el cambio de registro y el estilo del programa, puesto que desde la instancia de emisión se adopta para su tratamiento una distancia humorística. El resultado es que la audiencia suspende el pacto de credibilidad propio del discurso informativo e instaura otro basado en el placer de disfrutar con esa otra nueva contextualización de la información, hasta el punto de que, en ocasiones, se puede dudar de si lo cómico en estos casos pudiera ser también algo realmente serio (Massi 2008). El nuevo contexto proporciona un blanco del que burlarse y con él otros sentidos que se activan gracias a la complicidad que instaura el hecho humorístico, y que pueden ir de la pura broma al humor absurdo y carnavalesco, pasando por lo irónico y mordaz o la ridiculización del blanco. De ahí el efecto crítico de sátira política y social que se le suele reconocer a este humor mediático ${ }^{19}$.

\section{El humor como estrategia de captación de audiencia}

Los géneros paródicos basados en el humor informativo son principalmente programas de entretenimiento. Están guiados por un propósito de captación, cuyo objetivo es hacer sentir placer al espectador, de modo que se convierta en un fiel seguidor del programa. Se trata de una estrategia de programación determinada por un interés meramente económico y mercantilista que va dirigida a un público activo, el cual ha debido ser configurado, previamente, por el medio como target de audiencia. Ello requiere presuponer una experiencia compartida (basada en el sentido común, lugares comunes, prejuicios, tópicos, creencias, ideología) que pueda servir de puente entre la instancia de emisión y la instancia de recepción y facilite el reconocimiento del blanco humorístico. Igualmente, en tanto que el humor juega a oponer de forma brusca y sorprendente unas lógicas inesperadas a otras más habituales, han de suponerse para esos espectadores unas capacidades lógicas y deductivas semejantes a las de los guionistas que les permita asentir a la propuesta humorística, en especial cuando en el programa se manipulan conscientemente los esquemas argumentativos, para hacer pasar por válido y bueno lo

\footnotetext{
${ }^{19}$ De esta forma, la parodia informativa actúa como un contradiscurso: convierte en blancos los contenidos serios, esperando que sea aceptada esa perspectiva satírica de la realidad (Méndez Ga de Paredes 2004 y 2013).
} 
que en otro tipo de situación sería tenido como un fallo de razonamiento, una torpeza o un abuso (Iglesias Recuero 2009).

(2)

BM. Yorgos Papandreu anunciara que someterá a referéndum el segundo rescate a su país que se aprobó en la madrugada del viernes pasado en la UE// este plan supondría nuevos recortes y

privatizaciones para el país $\quad$ heleno $\uparrow / /$ Papandreu señaló que si el pueblo no lo acepta

entonces no se aplicará $\downarrow / /$ y de momento según una encuesta casi el $60 \%$ de los griegos se

muestra contrario al rescate $\S$

W: $\quad$ Sbah bah bah / las encuestas no sirven para nada $\uparrow / /$ lo dice el $90 \%$

de la gente [risas] // en cualquier caso si no se acepta la ayuda de la UE solo hay una manera de que

salgan de la crisis $\uparrow / /$ con auTOAYUDA $\downarrow / /$ el próximo presidente será Paulo Coelho [risas] (El

Intermedio1-11-2011) ${ }^{20}$.

Dicho de otro modo, intención humorística, mecanismos para transmitirla y efectos lúdicos asociados a dicha intención generan expectativas de audiencia, porque gracias al humor se crea un vínculo de comunicación solidaria y de participación del destinatario en el espectáculo que le hace sentir placer. A veces, incluso se alude a esta captación del auditorio o se hacen bromas con ella:

BM. uno de los problemas a los que tendremos que hacer frente en los últimos meses es / a la insistencia de la derecha ultramontana en repetir una y otra vez / mentiras /con la intención de que se conviertan en verdades // eso / por nuestra parte nos obliga a volver a los hechos tal y como ocurrieron para contrastar $\rightarrow$

W. $\mathrm{mmm}$ vamos lo que quiere decir Beatriz es que le vamos a regalar audiencia al Hormiguero $\uparrow$ (El Intermedio 24/10/2011)

\footnotetext{
${ }^{20} \mathrm{BM}=$ Beatriz Montañez y $\mathrm{W}=$ Wyoming.
} 
BM. La localidad gerundense de Olot apagará los semáforos por la noche para ahorrar $\uparrow$

W. mmm// ¿catalanes? $\uparrow /$ ¿ahorrar? $\uparrow / / /[$ gesto de desesperación] sí aquí hay un chiste pero no consigo verlo /// bueno ahí están las piezas/ ya vosotros os construís el chiste en casa// es un chiste IKEA [risas]/// (El Intermedio 26/10/2011).

El humor acerca psicológica y socialmente los espectadores al medio, pues, en esa negociación de sentido a que les obliga el discurso mediático, se les ofrece presupuesta una connivencia con la instancia de emisión. O sea, garantiza que se forma parte del grupo de los elegidos. En el juego de la interacción lúdica hay que seguir las reglas que lo conforman y que llevan que se acepte todo, por ejemplo, lo que concierne a los estilos de lengua y registros empleados, a tolerar y a admitir las asociaciones insólitas y las colisiones de mundos dispares que se proponen $\mathrm{y}$, sobre todo, a compartir el sistema de valores que se desea transmitir (Charaudeau 2006). Es decir, se les insta a una forma peculiar de integración y comunión con el medio, donde la complicidad funciona como un conjunto de referencias consabidas que poseen en exclusiva la instancia de emisión y el espectador (que automáticamente se configura en audiencia), y que determinarán el sentido e interpretación del discurso (Bustos Tovar 2009) ${ }^{21}$. En estos programas, la recepción e interpretación del humor requiere, por un lado, la comprensión de la intención o captación del marco lúdico en que se enuncia el mensaje (lo cual hace que se perciba el desajuste entre las expectativas contextuales que se poseen y el enunciado) $\mathrm{y}$, por otro, la aceptación o participación del punto de vista que sobre un determinado tema, persona, acontecimiento o situación ofrece el humorista. Esto último es lo que

\footnotetext{
${ }^{21}$ Una constatación de lo que se ha dicho lo proporcionan testimonios periodísticos de articulistas y columnistas, referidos a algunos de estos programas. "Menos mal que a continuación aparece el imprescindible Wyoming confirmándonos que la tele también puede estar habitada por gente insólitamente normal, con agradecible sentido del humor, con la que te puedes identificar, consolar y divertir" (Carlos Boyero: El Mundo 4/11/96). "Nunca había esperado la llegada del domingo como lo hago desde que el Gran Wyoming y su troupe de ingenios ahumados se dedican a asaltar a golpes de desenfado y talento a los mentirosos que están ahí fuera. Cuando empiezan a inundar la pantalla de Tele-5 los títulos de crédito, me pillan sentada en el diván, tamborileando los dedos sobre la falda con impaciencia, y lo que sigue nunca me defrauda. Caiga quien caiga es el equivalente televisivo y en los noventa de aquellas grandes experiencias de humor corrosivo, ironía sobre lo que nos pasa y saludable falta de respeto a los instituidos de turno que fueron las revistas Hermano Lobo y Por Favor [...] Caiga quien caiga es la mejor muestra de humor inteligente que aparece en estos momentos en la pequeña pantalla [...] Por favor, que se queden para siempre en los domingos de nuestra vida y que no decaigan" (Maruja Torres: El País 18/12/96).
} 
hace posible que en el proceso de recepción haya coincidencia entre el efecto pretendido que va asociado a la intención lúdica y efecto humorístico real (Kassaï 2001, Iglesias Recuero 2009).

La identificación del espectador con el programa se consigue a través del procedimiento enunciativo adoptado por el humor: una disociación entre la instancia que aparece como responsable del enunciado y la que asume la posición ideológica expresada en él. Un desdoblamiento polifónico de voces que se encaran dialécticamente para que el peso de la conclusión argumentativa se haga recaer en el humorista con la connivencia del espectador, el cual, en estos programas, asiente al desmontaje de una realidad sobre la noticia periodística, de las instituciones o de los actos de habla de los personajes públicos (ejemplos 5 y 6), a las que el humor pone una mirada gratificante, crítica y burlona, que hace disfrutar con todo ello.

BM: tenemos una nueva perla de González Pons $\uparrow$ / ayer en un acto en Valencia el vicesecretario de Comunicación del PP habló así // de los votantes del partido socialista [dentro vídeo con la intervención de Glez Pons en un total]

GP: Los españoles no quieren que gane el PSOE pero aún no tienen decidido si quieren que gane el Partido Popular $\rightarrow /$ los españoles tienen clarísimo que quieren cambio / porque no hay ningún español tan idiota que quiera continuidad a lo que quiere el PSOE / a lo que el PSOE nos ha dado durante todos estos años $\downarrow$ [vuelta al plató]

W: desde luego en esta campaña electoral el PP está siendo fiel a su nuevo lema $\uparrow / /$ ¡COMIENZA EL CAMBIO! // ahora ya no solo insultan a los políticos de otros partidos también insultan a sus votantes $\uparrow / /$ según González Pons los que piensan votar al PSOE son idiotas / la buena noticia es que según las encuestas cada vez hay menos idiotas en España $\uparrow$ [risas]/ la mala es que con este tipo de declaraciones González Pons se ha descubierto como un traidor $\rightarrow / /$ hay gente que sospecha que vota al PSOE $\uparrow$ (El Intermedio 24-10-2011)

(6)

Análisis de las opiniones que, la llamada por El Intermedio, "derecha ultramontana" vierte en el canal de TV Veo7 [entra vídeo con las imágenes de uno de los programas de esta cadena donde se ve y oye a Pío Moa (PM) hacer sus valoraciones sobre la existencia de ETA]

PM: ... si existe [ETA] es porque el gobierno socialista / Zapatero y sus gobiernos han colaborado con la ETA a los fines de la ETA y Zapatero ha sido el mayor colaborador que ha habido y debería estar en la cárcel / él y todos sus gobiernos si aquí hubiera justicia independiente

W: [vuelta al plató] pues os digo una cosaaa $\uparrow /$ ir a la cárcel es lo mejor que le podía pasar a Zapatero // se lo va a pasar en grande $\rightarrow$ /allí están todos sus colegas de ETA $\uparrow / /$ y luego cuando salga le puede pasar como a Mario Conde // convertirse en una estrella del TDT party $\downarrow / /$ además la cárcel es el único sitio donde nadie puede odiarle // allí ya están todos en el paro $\uparrow / / /$ ay // la TDT / carotistas / derecha / y teletienda [risas] (El Intermedio 24-10-2011) 
No obstante, el que los efectos pretendido y real sean coincidentes depende también de otros factores: del tipo de humor que se emplea, de la configuración del blanco sobre el que se hace la burla, de las relaciones entre los interlocutores internos (pero también de la relación entre la audiencia y el medio) o de la acomodación al contexto. En función de estos factores el espectador interpreta el humor de estos formatos como una estrategia de acercamiento afectivo o como una agresión intolerable, según se sienta o no emocionalmente a salvo. El de 7 puede ser un buen ejemplo para comprender esta ambivalencia de los efectos humorísticos:

BM: [Introduce la noticia de que el canal 13TV, propiedad de la Conferencia Episcopal, lanza el programa Más Íntimo, presentado por el sacerdote Javier Alonso. En pantalla aparece el cartel del programa: contra un fondo de edificios, pintados en estética de cómic, se recorta la figura de un sacerdote, recostado y apoyado en un codo. Las piernas están una encima de otra: de cintura para arriba viste de sacerdote con camisa gris y alzacuellos y de cintura para abajo, con vaqueros.]

W: [hace comentarios jocosos sobre la postura] [dentro un total de vídeo con la presentación del programa Más Íntimo: música sugerente, intimidad, voz en off femenina que dice: "Javier Alonso te invita a pasar un momento íntimo y personal" continúa música y entra en imagen Javier Alonso (JA.)]

JA: ¡Nos vemos sobre la media noche del viernes al sábado en Más íntimo!

W: [mirando a cámara y con entonación entre reflexión y adivinanza] un sitio oscuro $\uparrow / / /$ música sexy $\uparrow / /$ un trío insinuante $\uparrow / / /$ un cura que te propone algo más íntimo $\uparrow / / /$ ¿es el lugar perfecto para confesarte! $\rightarrow /$ solo con entrar ya estás pecando [carcajadas] ( $E l$ Intermedio 1-11-2011)

Ello ocurre porque lo humorístico es inestable, difuso y está siempre en la cuerda floja, de ahí que su delimitación vaya acompañada de ciertas dosis de subjetividad: es humor lo que cada sujeto considera tal en una determinada situación concreta, porque su procesamiento le proporciona una reacción psicológica y afectiva, originada al validar como humorístico un sentido sorprendente que está ligado a la ruptura de unas normas. Requiere, pues, reconocimiento de la intención, asentimiento al ethos humorístico y complicidad. De ahí que lo humorístico pueda ser considerado como una amenaza que ha de ser contraatacada. El ejemplo 8 muestra la portada del diario $A b c$ de 4 de abril de 1997 con los guiñoles de José Ma . Aznar y Ana Botella. El texto informativo de portada se hace eco de la idea de los dirigentes del Partido Popular de proponer un contraguiñol para salvar la imagen mediática de algunos líderes de su partido: 


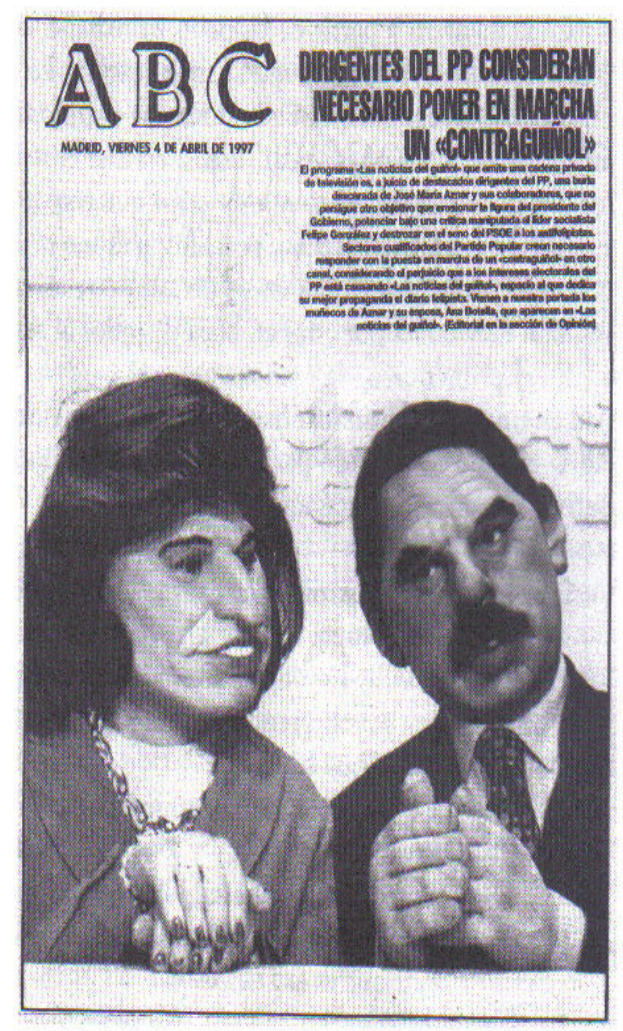

4. La parodia como procedimiento discursivo en el humor informativo

En todo acto humorístico hay una relación triádica en la que confluyen tres planos: el del enunciador, el del enunciatario y el del objetivo o blanco del humor (Bustos 2006 y Charaudeau 2006), que es precisamente el hecho sobre el que se proyecta la comunicación humorística. El blanco es aquello (individuo o grupo social, comportamientos y actitudes, ideas o defectos que se convierten en diana sobre la que lanzar los dardos del humor) sobre lo que se hace un tratamiento no serio para proporcionar una perspectiva diferente "desnudada" de los presupuestos y convenciones "habituales", y captar así "dimensiones de las situaciones que la cotidianidad y la costumbre han terminado por ocultar" (Hidalgo Downing/Iglesias Recuero 2009: 430 ${ }^{22}$, con la que se pretende una adhesión lúdica, capaz de producir efectos

\footnotetext{
22 De ahí que los objetivos del humor suelan presentarse como si fueran percibidos por subjetividades sociales muy distintas: unos se ofrecen como ahormados por la sociedad en su conjunto (o por un grupo social determinado), son los discursos autorizados y serios; los otros, que se juzgan como no serios, desajustados, graciosos, extravagantes o raros porque disienten de la norma colectiva, se atribuyen a minorías o sujetos poco capaces: ingenuos, niños, simples, locos, forasteros, etc.
} 
diversos (risa, evaluación crítica, exclusión social, solidaridad y sintonía, liberación de lo que nos oprime, subversión del orden imperante, defensa ante los cambios, etc.).

El humor se comunica mediante procedimientos discursivos: enunciativos y descriptivos ${ }^{23}, \mathrm{y}$ procedimientos lingüísticos. Los procedimientos enunciativos tienen un carácter polifónico (Ducrot 1984): señalan la confrontación en un mismo enunciado de varias perspectivas ideológicas que se yuxtaponen, se superponen y se replican, proporcionando orientaciones argumentativas contrapuestas que han de resolverse en un sentido o en otro, sin terminar de excluirse del todo esos sentidos contrapuestos. Los procedimientos descriptivos conciernen a la imagen del mundo que se construye mediante el humor. Lo distintivo es que esa descripción del mundo está fuera de norma, por lo que se juega con el contraste producido por la disociación entre lo representado descriptivamente en el enunciado y la imagen prototípica o habitual que se suele tener de esa realidad. El resultado es una distorsión o ruptura de la lógica que provoca algún tipo de incoherencia, pues obliga a poner en contacto universos de discurso incompatibles. Charaudeau (2006) propone distinguir tres tipos de incoherencia: insólita, paradójica y absurda, según hagan aflorar, respectivamente, un (trans)sentido, un (contra)sentido o, como en el absurdo, un (sin)sentido (Charaudeau 2006: 25-26). Sin embargo, la disociación no debe ser absoluta para que sea posible reconocer aspectos consustanciales de la realidad y otorgar sentido a la propuesta humorística. Por último, los procedimientos lingüísticos son mecanismos verbales, puestos al servicio del humor, que actúan en el nivel del enunciado. Se emplean para provocar una disociación de sentidos que permita pasar de una isotopía a otra (de un mundo de referencias y sentidos a otro), provocando un choque de universos de discurso y un cambio o ruptura de expectativas. Son mecanismos lingüísticos al servicio de la construcción del humor homonimia, polisemia, paronomasia, sinonimia, fijación léxica, desautomatización de frases hechas, calambur, etc. (Rivarola 1991, Gómez Capuz 2002, Ruiz Gurillo 2009). Sin que estos procedimientos sean en sí mismos signos de humor, funcionan como indicios internos del humor dentro de los

\footnotetext{
${ }^{23}$ La necesidad de diferenciar procedimientos discursivos y procedimientos descriptivos se discutió largamente en las sesiones de trabajo que se llevaron a cabo en el marco de una acción integrada del MEC El discurso humorístico como índice de socialización e identificación cultural. Una comparación España-Francia (HF2011-0087), algunos de cuyos trabajos son (Méndez G. de Paredes 2004 y 2006, Bustos/Cervera 2006, Charaudeau 2006, Vivero García 2006, Hidalgo Downing/Iglesias Recuero 2006.
} 
procedimientos humorísticos enunciativos y descriptivos señalados (Méndez $G^{\mathrm{a}}$ de Paredes 2013).

Desde un punto de vista discursivo, la enunciación humorística se caracteriza por un desdoble enunciativo en la instancia locutiva, de manera que no son homologables -por presentarse disociadas- la responsabilidad enunciativa y la perspectiva ideológica expresada en el enunciado. Dicho de otro modo, el proceso enunciativo para la coconstrucción del sentido comunicado hace interdependientes dos realidades: por una lado, la relación entre lo que se dice expresamente en el enunciado y la manera de decirlo y, por otro, lo que se desea que el destinatario interprete, obligándole a dar un sentido determinado a lo dicho como humor. Las diferentes categorías que pueden aparecer como invariantes discursivas en el continuum humorístico (ironía, sarcasmo, burla o juego burlesco y parodia) tienen en común un juego enunciativo entre decir y no decir, empleando para ello el decir y lo dicho.

Charaudeau (2006), propone diferenciar estas categorías del humor según el tipo de apreciación (positiva, negativa o neutra) que la instancia de emisión expresa en el enunciado pero no asume como responsable enunciativo. Según Charaudeau, la ironía se manifiesta como una disociación simultánea entre lo dicho y lo pensado, de manera que el acto de enunciación hace coexistir ambos como un sentido que el enunciado da de su enunciación (frente a lo que ocurre, p.e., en la mentira): lo expresado literalmente en el enunciado siempre es una apreciación positiva que oculta un pensamiento no dicho de valor negativo (2006: 27-29). El sarcasmo juega con una diferencia de grado dentro de la apreciación negativa con que se considera el objetivo o blanco del humor. Puede ser considerado un tipo de ironía en tanto que el mensaje literal y el sentido que ha de inferirse no coinciden, pero frente a la ironía en la que lo expresado literalmente supone una valoración positiva que encubre un sentido intencionadamente negativo, en el sarcasmo hay una insistencia sobre el valor negativo del blanco y su deformación ridiculizante, de modo que lo literal es exageradamente negativo, mientras que su sentido intencionado es negativo pero menos. El resultado es un decir agresivo (pues se dice lo que no debería ser dicho) que ha de ser interpretado según la fuerza de lo dicho (2006: 30-31). El juego burlesco o broma es el simple distanciamiento lúdico, que se produce sin ningún juicio de valor, como invitación a una complacencia lúdica mutuamente compartida por el enunciador y el enunciatario. El responsable del 
enunciado se desmarca de lo dicho sin mostrar su posición. Se corresponde con la suspensión del juicio de comicidad: el locutor dice con un tono imperturbable lo más inverosímil e insólito (Charaudeau 2006, Vivero García 2006).

Como los procesos interpretativos sobre los que se apoya la recepción del humor son básicamente de carácter inferencial, para que intención humorística y efecto humorístico estén en sintonía (o sea para que haya reconocimiento y aceptación de un mensaje humorístico) es determinante la calidad y cantidad de información pragmática compartida por los participantes, lo cual está en relación con la interacción de tres tipos de contextos: el lingüístico, el situacional y el sociocultural (Yus Ramos 2003, Curcó 1995). Ello, como se verá, es determinante para dar sentido a un humor mediático de tipo paródico.

La parodia es una de estas categorías del humor que juega con la enunciación, en el sentido de que en ella se intensifican y explotan los mecanismos intertextuales (Hutcheon 1981, Sangsue 1994, Pueo 2002). Es un tipo de citación que opera transformando lúdicamente un discurso anterior ${ }^{24}$ : hay copia de un modelo preexistente, si bien se cambian elementos estructurales de una forma insólita, de manera que sea evidente la alusión o referencia al discurso original, sin llegar a confundirse con él. La enunciación hace coexistir los dos textos que se alimentan recíprocamente dentro del texto paródico: el original queda como referencia y el paródico queda como imitación lúdica que se burla y cuestiona el original ${ }^{25}$. La parodia existe cuando podemos descubrir en la intersección de ambos planos de comunicación el efecto humorístico, lúdico, ridículo, crítico, de ahí que la captación de este nuevo discurso como fenómeno humorístico requiera previamente un reconocimiento del modelo parodiado.

Esta intertextualidad cómica puede ser concebida en términos de desvío, pues busca el contraste o choque de dos fuentes textuales distintas, sea por contacto o por evocación. El desvío (sea éste de carácter insólito, paradójico, ridículo, incongruente) proviene de

\footnotetext{
${ }^{24}$ Y no una simple copia como ocurre con el pastiche (Defays 1996, Charaudeau 2006)

${ }^{25}$ Obviamente, la parodia no puede confundirse con la intertextualidad: en la primera lo parodiado coexiste en su totalidad junto a lo paródico; en el segundo caso, los elementos trasvasados de un texto a otro adquieren una función discursiva y textual muy diferente que puede, incluso, llegar a borrar su procedencia. Dicho de otro modo, en la intertextualidad no existe imitación, sino signos de inscripción de la pertenencia a una tradición discursiva (Bustos 2009).
} 
la reutilización en un contexto "no serio" (que prescinde, pues, del compromiso con la verdad y la sinceridad) de un uso precedente que es reconocido en su deformación (Defays 1996, 1999). Esto implica que en la enunciación paródica deben seleccionarse y combinarse adecuadamente rasgos convergentes y divergentes con respecto al modelo original (sea en el plano de la forma, sea en el plano del contenido, sea en ambos planos). Se habla de travestismo burlesco (Defays 1996) cuando en la parodia se altera el estilo, pero no el tema. Es el caso de los formatos de humor de los que se ha venido hablando. En la parodia informativa estaríamos ante una desviación de la forma o estilo en que se dan las noticias, por lo tanto implica la adopción de un registro no apropiado con respecto a las expectativas proporcionadas por el género (vid. ejemplos 1 y 9):

Javi: vale entendido // bueno "El País" [gesto para dar entrada al recorte de prensa sobreimpreso con efectos especiales. Se queda inmóvil con el gesto interrumpido porque Juanjo le corta]

Juanjo: otra vez El País/ tú lo que quieres es que Polanco te suscriba a la plataforma esa digital que tanto le gusta a Cascos

Javi: pues no estaría mal no estaría mal [sigue con el gesto interrumpido] "El País" [clin-clon: sale sobreimpresa la noticia] "Defensa aplicará el cese forzoso a subordinados y jefes que tengan relaciones de afectividad"

Todos: ( ( (Aaaahhh!!! [gestos de horror]

Juanjo: Pero qué catástrofe sentimental es ésta (qué malos tiempos para el amor: primero destruyeron la pareja de la guardia civil [risas]

Wyoming: [asiente] es verdá!

Juanjo: ...y ahora echan del ejército a los que se lían [gestos de asentimiento y silencio]

Wyoming: bueno / es queee tampoco // como les dé por hacer una huelga de celo nos montan una guerra ¡claro!... y digo yo que esto es lo que tienen los militares / que si son máquinas pa matar también son máquinas pa... ff...

Javi: [interrumpiendo] ESO / eso se puede decir mucho más fino / sí sí sí sí / haz el amor y no la guerra sí

Juanjo: yo supongo que es que lo que quiere Trillo / la intención es que no haya líos entre empleado y subordinado pa evitar el acoso sexual en el trabajo // porque estos líos acaban siempre mal.

Javi: Pues es una pena porque se perderá eso de a mí la legión y todas esas cosas...

Wyoming: ¿¿A mí la legión?! /// como dijo Josefina en cuanto Napoleón salió por la puerta camino de Waterloo

Juanjo: es una pena / pero como dice ese verso tan espantoso "no está de moda practicar sexo" [risas ] (CQC, 18/5/2002, cit. en Méndez Ga de Paredes 2004)

También puede afectarse el contenido informativo. Es lo que se conoce como pastiche cómico, por ejemplo cuando se subvierten los valores periodísticos que caracterizan el género noticia y se incorporan a la parodia informativa contenidos banales o falsas noticias, testimonios deformados por el exceso de conformidad con los rasgos estilísticos del modelo informativo (hiperformalidad) (Defays 1996 y 1999). Es lo que sucede en 10, y en muchas de 
las informaciones que aparecen en El Mundo Today, pero también en lo que se ha referido al hablar del experimento de “docuficción”, Operación Palace (cf. supra).

[voz informativa en cola]: Este fin de semana ha fallecido el español medio $\rightarrow /$ el instituto español de estadística $\uparrow /$ ha convocado un concurso público para encontrar sustituto // las dificultades para encontrar una vivienda / y la precariedad laboral/ está motivando a muchos jóvenes españoles a regresar al útero materno $\rightarrow$ [en VTR testimonio de un joven que habla desde el interior del útero materno] ¿qué otra cosa podía hacer? $\uparrow /$ bueno a-aquí al menos tengo mi espacio $\uparrow(E l \text { Mundo Today } T V)^{26}$

La parodia como categoría del humor pone en tensión dos fuerzas contrapuestas: una de carácter estructural, que tiende a la construcción más o menos coherente por copia del modelo original y a seguir normas de un determinado género; otra tiende a liberarse y rechazar tales normas genéricas. Oscila, pues, entre conformidad y creatividad, al tiempo que permite constatar las normas existentes por no tolerarlas e innovar transformándolas. Como señala Umberto Eco, lo importante del procesamiento humorístico es la idea de "conocimiento de regla violada" (de ahí lo cultural ligado al humor), pero, sobre todo, el hecho de dar la regla por descontada, sin necesidad de tener que reiterarla: "existe un artificio retórico que concierne a las figuras de pensamiento, por el cual, dada una disposición social o intertextual, ya conocida por la audiencia, muestra su variación sin por ello hacerla discursivamente explícita" (Eco 1980: 372) Los formatos mediáticos de televisión se construyen como parodia informativa: no solo por relación con modelos o géneros ya establecidos (parodia en sentido estricto): Las noticias del guiñol, Caiga quien caiga, El Intermedio, etc. que copian los informativos televisivos, deformándolos, sino en relación a lo "serio" en general, que es con lo que contrasta y de lo que se nutre (parodia en sentido amplio) ${ }^{27}$.

5. El molde comunicativo elegido

El humor mediático de la parodia informativa suele construirse sobre la base del diálogo, desarrollado gracias a la complementariedad de los roles desempeñados por los humoristasperiodistas que se alternan en el uso de la palabra. Es aquí donde menos varía la parodia

\footnotetext{
${ }^{26} \mathrm{http}: / /$ www.youtube.com/watch?v=T6YTrzwbCAw\&list=PL32CACA2D29E28F13\&feature=player_e mbedded (última consulta el 29/12/2013).

${ }^{27}$ El humor aparece así como un infradiscurso pues no tiene más estatuto que el proporcionado por esos otros discursos.
} 
informativa como espectáculo televisivo y como espectáculo radiofónico. Los rasgos distintivos del diálogo y la conversación hacen de estos géneros las formas del discurso que mejor se prestan a transmitir el humor (Dynel 2009, Norrick/Chiaro 2011). La oralidad coloquial, como medio de transmisión (pero también como concepción del discurso), está más acorde con la finalidad lúdica por el carácter improvisado y espontáneo que suele tener el humor. El molde de lo conversacional proporciona un efecto y una apariencia de agilidad mental cuando se proponen asociaciones inesperadas y sorprendentes. De hecho, muchos de los programas se emiten en directo o en falso-directo para ofrecer una imagen de inmediatez, espontaneidad y cercanía. Igualmente, el dinamismo en la alternancia de la palabra, la elaboración conjunta y en cooperación de los temas, el tono familiar y de proximidad, el conocimiento mutuo, las alusiones a lo consabido, la elusiones intencionadas, las características del espacio interlocutivo, la manifestación de relaciones interpersonales de solidaridad y sintonía, etc. (que son rasgos que tipifican y describen la conversación coloquial como protogénero de la oralidad), facilitan la fluidez del mensaje humorístico. De este modo, parece como si la transmisión del humor a un tercero (o sea, el humor como espectáculo), fuera más fácil de canalizar a través de la mímesis de una conversación.

En todos los programas que se han citado hay que delimitar dos niveles de comunicación: un nivel inter-personajes o inter-presentadores, y un nivel presentadoresaudiencia (mirada frontal a la cámara, formas de apelación directa) donde se crean los efectos humorísticos. Los presentadores siguen un patrón estereotipado, alternan sus roles (saludos, dar entrada al humor proporcionando un correlato serio con el que enfrentar el tratamiento lúdico) y su voz aparece en secuencias de paso, cola o interrumpida por totales o VTR ${ }^{28}$ (Méndez $G^{\text {a }}$ de Paredes 2013). La técnica consiste en unir dentro de un intercambio -o secuencia de intercambios temáticamente ligados- una intervención iniciativa (L1) de carácter informativo (acompañada de las rutinas propias de un informativo de televisión serio), que constituye el soporte referencial de los hechos: lo serio; y una intervención reactiva de carácter lúdico (L2), interpretada como

\footnotetext{
${ }^{28}$ Con el término paso se conoce las partes del informativo en las que las cámaras recogen la imagen del locutor que habla. En el caso de cola, se oye la voz del presentador aunque este no aparece en pantalla, porque en ese momento se están pasando imágenes relacionadas con las noticias que relata. Los totales son las declaraciones hechas por los protagonistas de las noticias y pueden aparecer dentro de un vídeo montado previamente (VTR) o como piezas sueltas.
} 
una réplica a lo dicho por L1, y que constituye la otra cara de la noticia: el comentario del hecho informativo. Acontecimiento referido (AR es la noticia, a cargo de L1) y acontecimiento comentado (AC es la evaluación de la noticia, a cargo de L2) (Charaudeau 2003) ${ }^{29}$ constituyen, pues, un patrón regular. Como se ha estudiado en Méndez $G^{\text {a }}$ de Paredes 2013, el cambio de locutores actúa como una señal demarcativa que ordena la inserción del humor y prepara al auditorio para su recepción. Desde un punto de vista informativo el turno de L2 es de carácter remático: aporta el contenido relevante de la interacción. Aquí es donde hay que rastrear: (a) los indicios externos (gestos, entonación, elocución) que orientan lo que se va a decir para que sea interpretado como humor, (b) los rasgos distintivos o procedimientos enunciativos y descriptivos que funcionan como rasgos pertinentes del humor y (c) los indicios internos o los procedimientos lingüísticos que aparecen en el nivel del enunciado (juegos de palabras, asociaciones metalingüísticas, etc.):

BM: tenemos una nueva perla de González Pons $\downarrow$ / ayer en un acto en Valencia el vicesecretario de Comunicación del PP habló así // de los votantes del partido socialista

GP: [dentro vídeo con la intervención de González Pons en un total] los españoles no quieren que gane el PSOE pero aún no tienen decidido si quieren que gane el Partido Popular $\rightarrow /$ los españoles tienen clarísimo que quieren cambio / porque no hay ningún español tan idiota que quiera continuidad a lo que quiere el PSOE $\rightarrow$ / a lo que el PSOE nos ha dado durante todos estos años [vuelta al plató]

W: desde luego / en esta campaña electoral el PP está siendo fiel a su nuevo lema $\uparrow_{/ i}$ COMIENZA EL CAMBIO! $\uparrow / /$ ahora ya no solo insultan a los políticos de otros partidos también insultan a sus

votantes $\uparrow / /$ según González Pons los que piensan votar al PSOE son idiotas $\rightarrow$ / la buena noticia es que

según las encuestas cada vez hay menos idiotas en España $\uparrow$ [risas del público]/ la mala es que con este

29 Para las nociones de acontecimiento referido (AR) y acontecimiento comentado (AC) sigo a Charaudeau (2003: 190-219): la intervención iniciativa de L1 propone una visión del mundo de tipo constatativo, mientras que la reactiva de L2 propone una visión de carácter explicativo. En ella se da como probado el hecho constatado por la información y presupone su veracidad; se trata entonces de aventurar lo que significa en un proceso de "dilucidación" que revele lo que está oculto, descubriendo las intenciones que hay tras los hechos (esto se puede hacer mediante un encadenamiento lógico causa-efecto o mediante un razonamiento analógico o desarrollando estudios de caso, es decir, haciendo hipótesis sobre guiones posibles) (217-219). Como señala Charaudeau, además de dilucidar, el comentario puede “problematizar" la información preguntándose por su "normalidad" a la par que ofrece una manera de tratarla, y puede también evaluar emitiendo una apreciación subjetiva que proyecta su afectividad. 
tipo de declaraciones González Pons se ha descubierto como un traidor $\rightarrow / /$ hay gente que sospecha que vota al PSOE $\uparrow$

BM: tras desatar la indignación de los socialistas / González Pons pide disculpas a través de twiter con estas palabras // [en pantalla imagen del tuit y, en cola, lectura en voz alta de las palabras de GP.] "el PSOE me acusa de insultarles. No es verdad. Pero no le voy a dar más vueltas. Si alguien se siente ofendido retiro la palabra. Mis disculpas"

W: es lo que Gonzáles Pons llama pedir disculpas y lo que en las parejas se conoce como [elocución rápida] "te digo lo que quieras con tal de no seguir discutiendo" $\downarrow$ [risas del público] si quería haber pedido disculpas de verdad debería haber dicho directamente // "la he cagao / lo siento" [risas del público]. (El Intermedio 24/10/2011)

La intervención de L2 (Wyoming) comenta el acontecimiento informativo previo e intenta una explicación de lo acontecido dentro de una lógica política actual. El marcador desde luego abre este proceso reafirmando como evidente la secuencia "en esta campaña electoral el PP está siendo fiel a su nuevo lema8//iCOMIENZA EL CAMBIO! $\uparrow$ a la vez que la conecta polifónicamente con quienes también la sostienen (los militantes del Partido Popular). En un nuevo movimiento enunciativo la intervención prosigue con la inserción de una secuencia que aventura qué significa para L2 “comienza el cambio", y es aquí donde se opera el proceso de disyunción que descontextualiza el lema del PP para integrarlo en otro contexto que se describe ("de insultar a los adversarios a insultar a la población que los vota”). Sigue el proceso de dilucidación con un encadenamiento lógico causa-efecto que contrapone datos y sirve nuevamente como armado para la integración de una secuencia que convierte a González Pons en blanco de la burla, a partir de un silogismo implícito: "según González Pons los votantes del PP son idiotas", su declaración es idiota (valoración implícita), luego González Pons es idiota: por lo tanto vota al PSOE, por lo tanto es un traidor". El formato informativo serio acontecimiento referido/acontecimiento comentado (AR/AC) actúa como "disfraz" de un encadenamiento argumentativo que propone disyunciones paradójicas para dar otro sentido a la información y convertirla en blanco del humor. Lo mismo ocurre en la réplica del siguiente intercambio: la explicación a un nuevo AR trata de revelar algo oculto tras las disculpas de González Pons a través de un razonamiento analógico de carácter descriptivo: "lo que en las parejas se conoce como te digo lo que quieras con tal de no seguir discutiendo", que actúa de disyuntor al proponer un contexto doméstico para una rectificación política. La disculpa se vuelve objeto o blanco del humor y queda descalificada en la analogía propuesta. Se refuerza esta descalificación gracias a la expresión vulgar "la he cagao". 


\section{Los blancos de humor y el efecto crítico}

El discurso informativo en cualquiera de sus múltiples vertientes es el objetivo de este humor paródico. Especialmente los dardos del humor hacen blanco en la noticia como discurso, es decir, como relato de acontecimientos de cierta trascendencia social y política en los que se ven envueltos personajes de la vida pública. Y también en la noticia como transmisora de discursos y actos de habla de los protagonistas del discurso informativo (políticos, agentes sociales, etc.). El discurso informativo serio no hace más que consolidar el estatus social de estos personajes y los inviste de autoridad y legitimidad para hablar a través de los medios. Uno de los rasgos de este humor informativo paródico es el de la degradación de la imagen pública de los individuos y de los grupos de poder a partir de la frivolización de sus discursos (Hidalgo Downing/Iglesias Recuero 2006, Méndez Ga. de Paredes 2004 y 2006). El humor manipula intencionadamente lo que dicen: atendiendo a la manera en que se verbalizan los discursos (tics, muletillas, hábitos de pronunciación, expresiones repetidas que sirven para identificar y reconocer a los sujetos, imitación caricaturesca, por ejemplo en el humor de los guiñoles), o parodiando los contenidos dichos, como en el ejemplo 12, en el que Ana Botella, esposa de José $\mathrm{M}^{\mathrm{a}}$ Aznar, es ridiculizada por los periodistas de Caiga quien caiga. Estos ponen el foco en la banalidad de los contenidos dichos y en la ideología que los sustenta. Para ello, descontextualizan sus actos de habla y los insertan luego en un contexto totalmente inapropiado. Con ello se critica el aprovechamiento por parte de Ana Botella de los medios públicos para impartir ideología, cuando su marido era presidente del Gobierno:

Wyoming: bien / ha llegado esa hora [elocución de anuncio de buena nueva] que todos ustedes estaban esperando // los dos minutos de de gloria en los que la audiencia se arremolina en torno al televisor para escuchar las sabias palabras de nuestra colaboradora /// (b) Ana (b) [risas de plató]

Juanjo y Javi: [cantando a coro] bien...bien [dando palmas] Ana Botella...Ana Botellaaa

Wyoming: simplemente Ana /// [volviéndose hacia los monitores] // buenas tardes Ana

Ana: buenas noches Ricardo

Wyoming: ah...lo que tú digas Isabel // bueno hay un e-mail que nos ha enviado Paloma Pascual que nos pregunta tu opinión acerca de la salida de la cárcel de Roldán y nos dice / leo / Querida Ana ¿no te parece raro que después de lo que costó meterle en el trullo / Roldán salga de la cárcel y encima gobernando el PP con mayoría absoluta?

Ana: Pues sí / la verdad es que todo esto podría ser el guión de una película de entretenimiento si en el fondo no fuera tan preocupante.

Javi: (mmm! ¿Quieres decir que todo esto te preocupa además de como política como mujer en concreto? 
Ana: los que compramos el pan todas las mañanas / los ciudadanos que andamos por la calle no nos merecemos esta farsa.

Juanjo: ¿Os habéis fijado? Es ella la que sale a comprar el pan y va andando a los sitios como un ama de casa española más.

Wyoming: bien / bien tranquilo Juanjo y volvamos con Ana // bien te has referido al caso como una película... como una farsa / ¿no crees que por lo que colea sería más bien un culebrón?

Ana: tengo la impresión de que todo esto es un espectáculo con el que nos divertiríamos si no fuera porque los cómicos son malos y el argumento pone en cuestión la dignidad del país en que vivimos.

Juanjo: ¡hombree! Y no solamente de ESPAña / sino de allí por donde pasó hasta que le pillaron /// ¿te acuerdas? [con complicidad] ¡qué tiempos aquéllos!

Ana: Lisboa, París, Argentina, Laos, Bangkok, Madrid...

Javi. ah...eh...halaa si parece que estuvieras concursando en el "un dos tres" [risas del plató] si sólo faltan los premios

Juanjo. talmente

Ana. coches, motos, aviones privados, cámaras de televisión, fotógrafos...

Wyoming: muy bien...je...je muy bien ¡exacto! // bien ¿alguna cosa más que te preocupe Ana?

Ana: pues sí / nuestros impuestos // y sobre todo // la soberanía y el buen nombre // de un país mediterráneo que no es del trópico ni bananero que se llama España

Juanjo y Javi: [cantando a coro] bieeen [aplaudiendo] (Españaaa! No bananeroo oleee

Wyoming: vale...vale si vale / no os vengáis arriba // bien Ana bonita cada día lo haces mejor / como le dijeron a Josefina en su momento

Ana: ¡muchas gracias! (“El consultorio de Ana”, Caiga quien caiga, 1/12/2002)

La burla y la ridiculización de los discursos lleva a la desvalorización de los sujetos que los emiten, por eso el discurso humorístico es dependiente de la palabra que circula por los medios informativos: se cita, incluso literalmente, pero el marco contextual que permite la integración de lo reproducido en un nuevo discurso no pretende ser fiel a la situación enunciativa originaria (Galatanu 1993). De este modo, los protagonistas de la noticia se quedan desprotegidos porque la parodia no los enfoca como su estatus requeriría y ello es perturbador para su imagen mediática. El humor de la parodia informativa, además de lúdico, es crítico, es sátira política $\mathrm{y}$, como tal, emplea una técnica de desvalorización de su blanco, rebaja su dignidad (mediante el estilo y el lenguaje). Se destruye así el aparato simbólico que los envuelve mediante la técnica del desnudado, haciendo que se vean despojados de lo que los convierte en tales símbolos. De este modo, las diferentes categorías del humor: parodia, ironía, sarcasmo y burla son requisitos imprescindibles de la sátira (Hodgart 2010: 28).

\section{Conclusión}

En España, los informativos humorísticos (infosátira) se construyen como los serios, a partir de la base documental que proporciona el discurso informativo de la televisión, de la radio o 
de la prensa, más el acopio documental propio. Pero frente a los informativos serios, que se limitan a transmitir y analizar desde una ideología determinada los acontecimientos noticiosos, el humor mediático de la parodia informativa saca a la noticia del mundo de los acontecimientos y de sus contextos de referencia, y crea para ella otro mundo posible construido desde una perspectiva totalmente distinta de carácter lúdico: confiere otro estatuto al discurso informativo y paralelamente lo comenta irónicamente en forma de metadiscurso que replica de un modo transgresor al discurso oficial de los medios (Bertrand 1993), convirtiendo el humor en una cosa seria (Massi 2008).

Bibliografía

BERTRAND, Denis (1993): "Ironie et humour: le discours renversant", Humouresques, 4. Sémiotique et Humour, 27-41.

BUSTOS TOVAR, José Jesús (2009): “El humor gráfico. ¿Humor informativo?”. Ponencia presentada en las Jornadas sobre Información y Manipulación en el Discurso Mediático. Sevilla del 21 al 23 de octubre de 2009.

BUSTOS TOVAR, José Jesús y Ángel CERVERA RODRÍGUEZ (2006): “Un proyecto de trabajo: análisis discursivo del chiste gráfico". En CASADO VELARDE, Manuel, GONZÁLEZ RUIZ, Ramón y Mavictoria ROMERO GUALDA (eds). Análisis del Discurso: lengua, cultura, valores. Madrid: Arco Libros, 233-263.

CASSETTI, Francesco y Frederico DI CHIO (1999): Análisis de la televisión: instrumentos, métodos y prácticas de investigación. Barcelona: Paidós.

CHARAUDEAU, Patrick (1989): "Le dispositif socio-communicatif des échanges langagiers". Verbum XII, 1. Presses Universitaires de Nancy, 13-25.

CHARAUDEAU, Patrick (2003): El discurso de la información mediática. La construcción del espejo social. Barcelona: Gedisa.

CHARAUDEAU, Patrick (2006): “Des categories pour 1'humour?”. Questions de Communication, 10, 12-54.

DEFAYS, Jean-Michel (1996): Le comique. Paris: Seuil. 
CORTES, José Ángel (1999): La estrategia de la seducción. La programación en la neotelevisión. Pamplona: EUNSA.

CURCO, Carmen (1995): "Some observations on the pragmatics of humorous interpretatitions. A relevance-theoretic approach". UCL Working Paper in Linguistics, 7, 27-47.

DEFAYS, Jean-Michel et Laurence ROSIER (1999): Approches du discours comique. Liège: Pierre Mardaga.

DUCROT, Oswald (1984): El decir y lo dicho. Polifonía de la enunciación. Barcelona: Paidós.

DYNEL, Marta (2009): "Beyond a joke: types of conversational humour”. Language and Linguistics Compass 3, 1284-1299.

ECO, Umberto (1983): "Lo cómico y la regla". En La estrategia de la ilusión. Barcelona: Editorial Lumen, 368-378.

ECO, Umberto (1983): "La transparencia perdida". En La estrategia de la ilusión. Barcelona: Editorial Lumen, 200-223.

GALATANU, Olga (1993), "Le discours de la dérision politique et la dérision du discours politique". Humoresque, 4, Sémiotique et Humour, 69-80.

GÓMEZ CAPUZ, Juan (2002): “Mecanismos del lenguaje humorístico (con especial atención al nivel pragmático)”. Oralia, 5, 75-101.

HIDALGO DOWNING, Raquel (2009): "Informar, hacer reír, hacer oposición, persuadir: funciones del humor en el discurso mediático". Ponencia presentada en las Jornadas sobre Información y Manipulación en el Discurso Mediático. Sevilla del 21 al 23 de octubre de 2009.

HIDALGO DOWNING, Raquel y Silvia IGLESIAS RECUERO (2006a): "Humor y discurso crítico. El estilo de la noticia humorística radiofónica como crítica del discurso periodístico". En CASADO VELARDE, Manuel, GONZÁLEZ RUIZ, Ramón y Mªvictoria ROMERO GUALDA (eds). Análisis del Discurso: lengua, cultura, valores. Madrid: Arco Libros, 2275-2293. 
HIDALGO DOWNING, Raquel y Silvia IGLESIAS RECUERO (2006b): "Humor y cortesía en los medios de comunicación: la entrevista". Comunicación presentada en el III Coloquio Internacional del Programa EDICE. Universidad de Valencia, 22-26 de noviembre de 2006.

HODGART, Matthew (2010): Satire. Origins and Principles. Transaction Publisher [1969]- New Jersey: New Brunkswick.

HUTCHEON, Linda (1981): "L'ironie, satire et parodie: una approche pragmatique de l'ironie". Poétique 46, 275-298.

IGLESIAS RECUERO, Silvia (2009): "El humor, una manipulación del discurso socialmente consentida". Ponencia presentada en las Jornadas sobre Información y Manipulación en el Discurso Mediático. Sevilla del 21 al 23 de octubre de 2009.

KASSAII, Georges (2001): “Humour et connivence”, en LAURIAN Anne-Marie y Thomas. SZENDE (eds.), Les mots du rire: comment les traduire? Oxford: Lang, 155-164.

MASSI, Ma Palmira (2008): "El humor es cosa seria. Discursos transgresores en la prensa alternativa norpatagónica”. Comunicación y Medios 18, 155-175.

MÉndez Ga DE PAREDES, Elena (1999): “Análisis de la reproducción del discurso ajeno en los textos periodísticos". Pragmalingüística, 7, 99-128.

MÉndez Ga DE PAREDES, Elena (2004): "Humor y televisión en España”. En Merlo, Philippe et Begoña RIESGO (eds.): L’humour hispanique, Lyon: Université Lyon II, 147-190.

MÉNDEZ Ga DE PAREDES, Elena (2006): "Humor y discurso referido". En CASADO VELARDE, Manuel, GonzÁlez RuIZ, Ramón y MaVictoria Romero GuAldA (eds). Análisis del Discurso: lengua, cultura, valores. Madrid: Arco Libros, 1483-1503.

MÉNDEZ Ga DE PAREDES, Elena (2013): “Discursive mechanisms of informative humor in Spanish media”. En Ruiz-Gurillo, Leonor y M. Belén Alvarado-OrTEGa (eds.): Irony and Humor. From pragmatics to discourse, Amsterdam: Benjamins, 85-106.

NORRICK, Neal R. y Delia CHIARO, eds. (2011): Humor in Interaction. Amsterdam: Benjamins. 
PUEO, Juan Carlos (2002): Los reflejos en juego (Una teoría de la parodia). Valencia: Tirant lo Blanc.

RIVAROLA, José Luis (1991), "Signos del humor”, en Signos y significados. Ensayo de semántica lingüística. Pontificia Universidad Católica del Perú, 91-108.

ROSSEN-KNILL, Deborah F. y Richard HENRY (1997): “The pragmatics of verbal parody”. Journal of Pragmatics, 27, 719-752.

SANGSUE, Daniel (1994): La parodie. Paris: Hachette.

SANGRO, Pedro y Alejandro SALGADO (2008): El entretenimiento en TV: guión y creación de formatos de humor en España. Barcelona: Laertes 2008.

VALHONGO CREGO, Luis (2011): Sátira televisiva y democracia en España: la popularización de la información política a través de la sátira. Barcelona: UOC.

VAN DIJK, Teun A. (1990): La noticia como discurso. Comprensión, estructura y producción de la información. Barcelona: Paidós.

VIVERO GARCÍA, Ma Dolores (2006): "Procedimientos discursivos y formas de humor en las columnas periodísticas francesas y españolas”. Sintagma, 18, 67-80.

YUS RAMOS, Francisco (2003): "Humor and the search for relevance". Journal of Pargmatics, 35, 1295-1331.

Recibido: 31 de marzo de 2014 Aceptado: 30 de septiembre de 2014 Publicado: 30 de septiembre de 2014 Actualizado: 14 de octubre de 2014 